\title{
MAJOR PARAMETERS SITE SELECTION OF WALA DAM
}

O.Dhaimat,

Isra Univ., Jordan

(Received February 24, 2009 Accepted March 18, 2009)

Water is an important substance for human kind and other survivals on the earth due to its role for their growth, survive, and activities. For that, it covers more than seventy percent of the earth surface and human body weight. But, unfortunately most of the water is saline and available fresh water doesn't increase one percent.

Earth is divided into four zones based on the rainfall amount and meteorological factors known as humid, semihumid, semi-arid, and arid. Their annual rainfall more than $600 \mathrm{~mm}, 300-600 \mathrm{~mm}, 100-300 \mathrm{~mm}$, and less than $100 \mathrm{~mm}$ respectively.

Jordan is located in semi arid region which faces day by day a shortage of rainfall and fewer amounts of surface and groundwater. These conditions force the public sector to work hard for obtaining new water resources in order to match the incremental of population growth and water demand. Dams consider preferable structures of collecting surface water and recharging ground water during winter season. But, it needs a lot of study and using latest fashions of tools and technology for site selection and dam construction in order to reach required goals with proper means. Remote sensing and geographical information system consider suitable tools of collecting, input analysis, and output data.

Wala dam was the attractive one to study the necessary selecting parameters of site selection by using these tools in popular way for planners and decision makers in Jordan.

KEYWORDS: Water, Jordan, Dam, Surface water, Ground water, Remote sensing, Geographic Information System.

\section{INTRODUCTION}

Water is vital substance for human kind due to its role in their life, activities, and economy. This turn becomes so clear in semi arid regions, where the rainfall is so small and the surface and ground water is not that much.

Jordan locates in semi arid area of the Middle East region where more than $80 \%$ of the country receives rainfall less than $100 \mathrm{~mm}$ annually. One of the popular methods of saving water for domestic, business, and agriculture uses is building dams at streams and wadies in order to receive the surface runoff during winter season.

Dams as unique structures need a lot of efforts through its feasibility study, establishment, and development. Otherwise it will create a lot of problems which are beyond the ability of the government and the society in overall.

Majority of the required parameters for dam site selection are related to hydrology, topography, soil, geology, society, and economy. Out of these, soil 
characteristics consider very important factors due to its side effects towards water quantity and water quality of dam reservoir, and stability and safety of dam.

Wala dam was the attractive case study of the writer of this paper because of its location, methodology of study and dam establishment, normal and abnormal difficulties, and the change of the dam object according to that variation.

\section{STUDY AREA}

As shown in fig 1 , Wala dam is located at $40 \mathrm{Km}$ south of Amman city and at $4 \mathrm{Km}$ east of Wala bridge along King Road within Madaba governments.

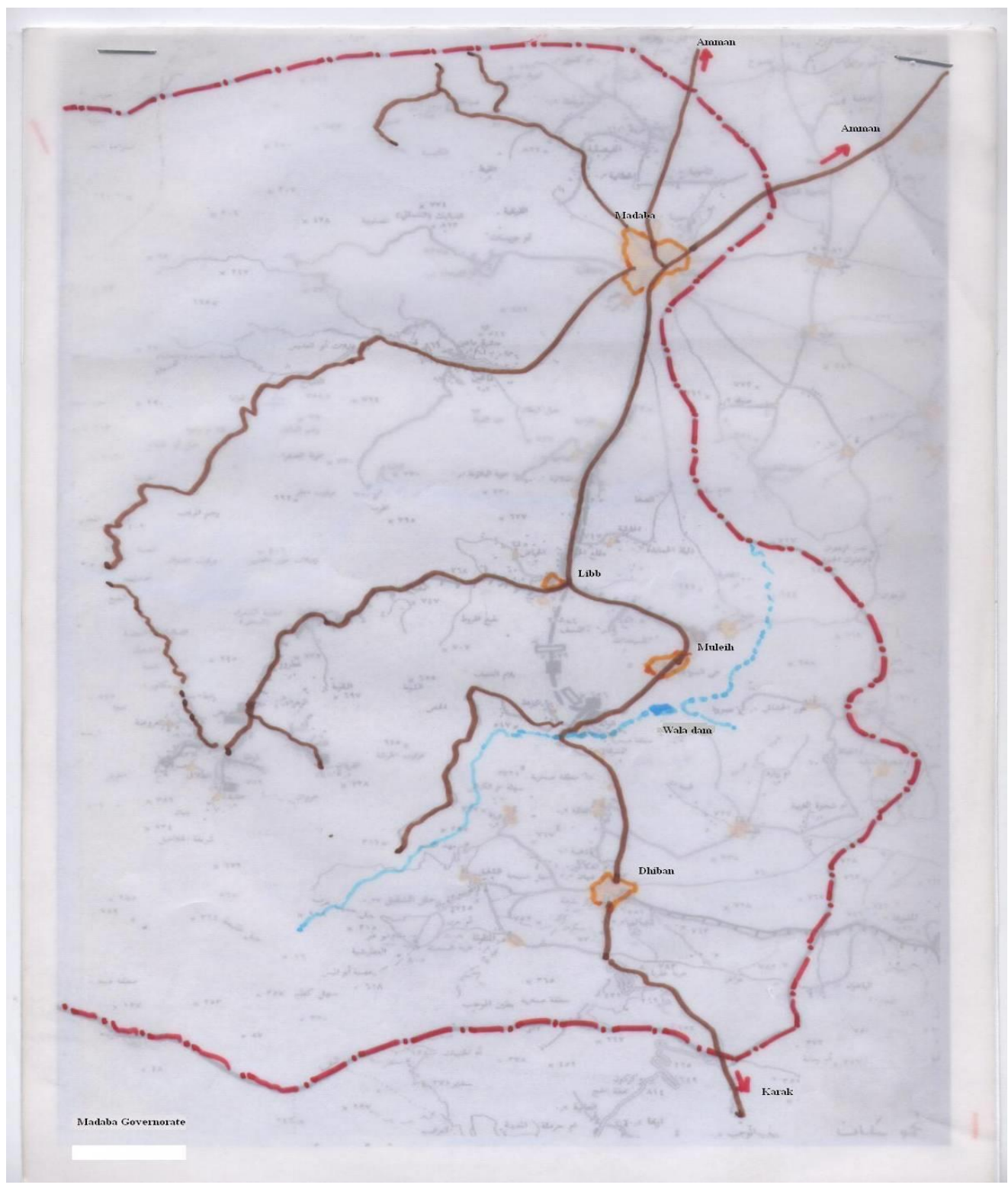

Fig 1 .Location of Wala dam 
The final object of the dam establishment was to improve floodwater for recharging Wadi Sir Aquifer in haidan region to supply Amman city with 3.5 MCM of potable water each year. Also, it provides compensation water for the benefit of downstream farms and to reply with the needs of some industries and tourism activities at that area.

With reference to fig 2, the watershed covers area around $2000 \mathrm{Km}^{2}$ eastern of Dead Sea and northen of Wadi Mujib basin. The majority of the catchment area lies at elevation of 700-900 m east of the hills marking the edge of the Jordan Valley escarpment. In the west part of the watershed, the wadies have cut deep gorges through escarpment and some of them form springs due to reaching saturated water bearing formation at their lower reaches.

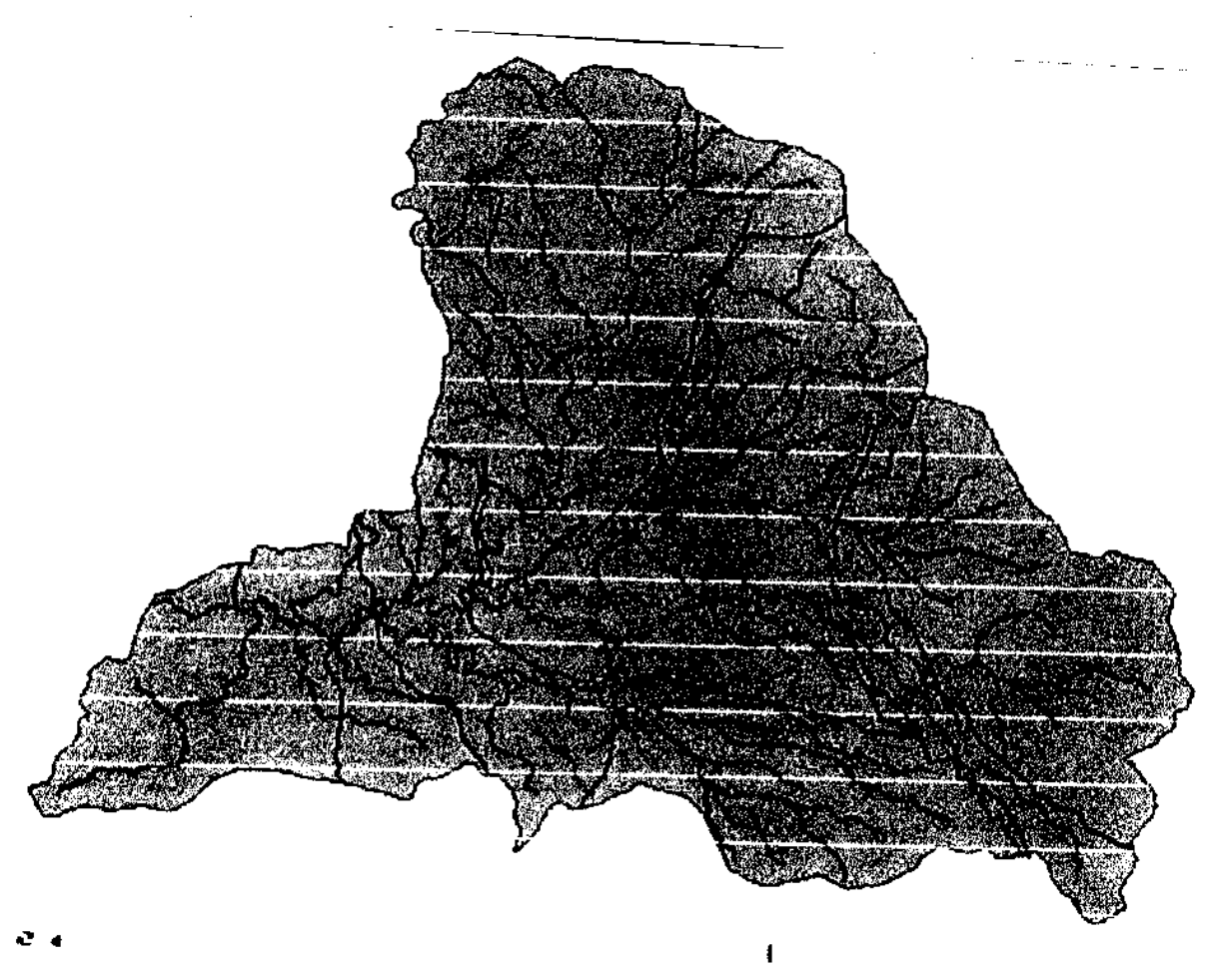

Fig 2 . watershed of study area

MATERIALS AND DATA COLLECTIONS:

The selective method used in the present study is known as elimination method. Its philosophy based on the intersected of various basic maps of drainage, slope, land use, and land cover with each other to produce compound maps, and then in sequence these maps produce other maps till reaching a map of four options of erosion sensitive sheet which is considered the most important factor affecting site selection of dam. Fig 3 represents the outline of this model. 


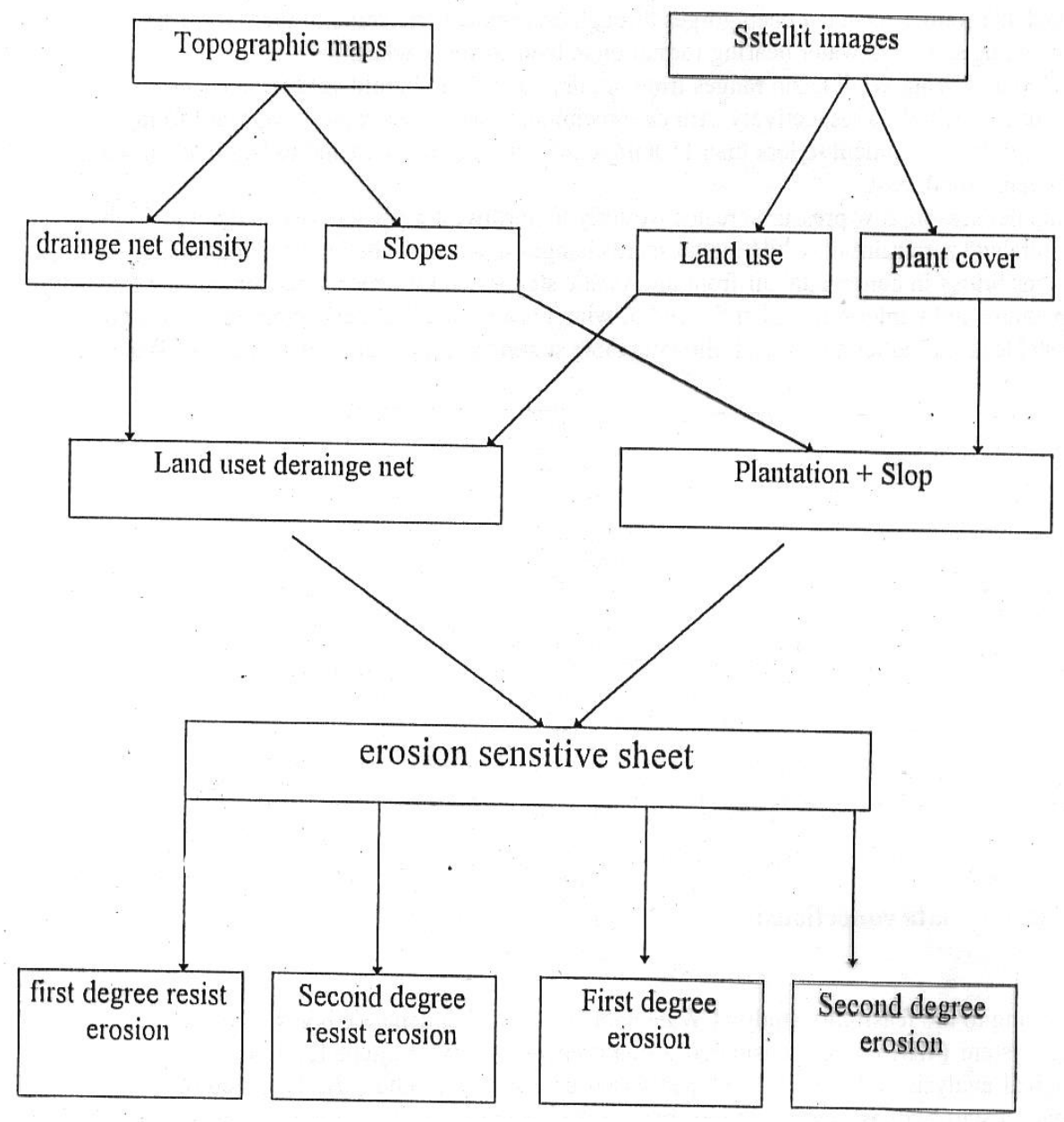

Fig 3.Out line of elimination method

This method deals with two types of modern technology; remote sensing (RS) and geographic information system (GIS).The former is considered the tool of collecting data of dam site selection besides topographic maps, records, and field work. The latter is the home of data input, analysis, and output by using sophisticate computers and software.

The strategy of this method involves planning, field reconnaissance, feasibility study, site selection dam type information, dam site investigation, dam design, and dam construction. Fig 4shows stages of dam site selection. 


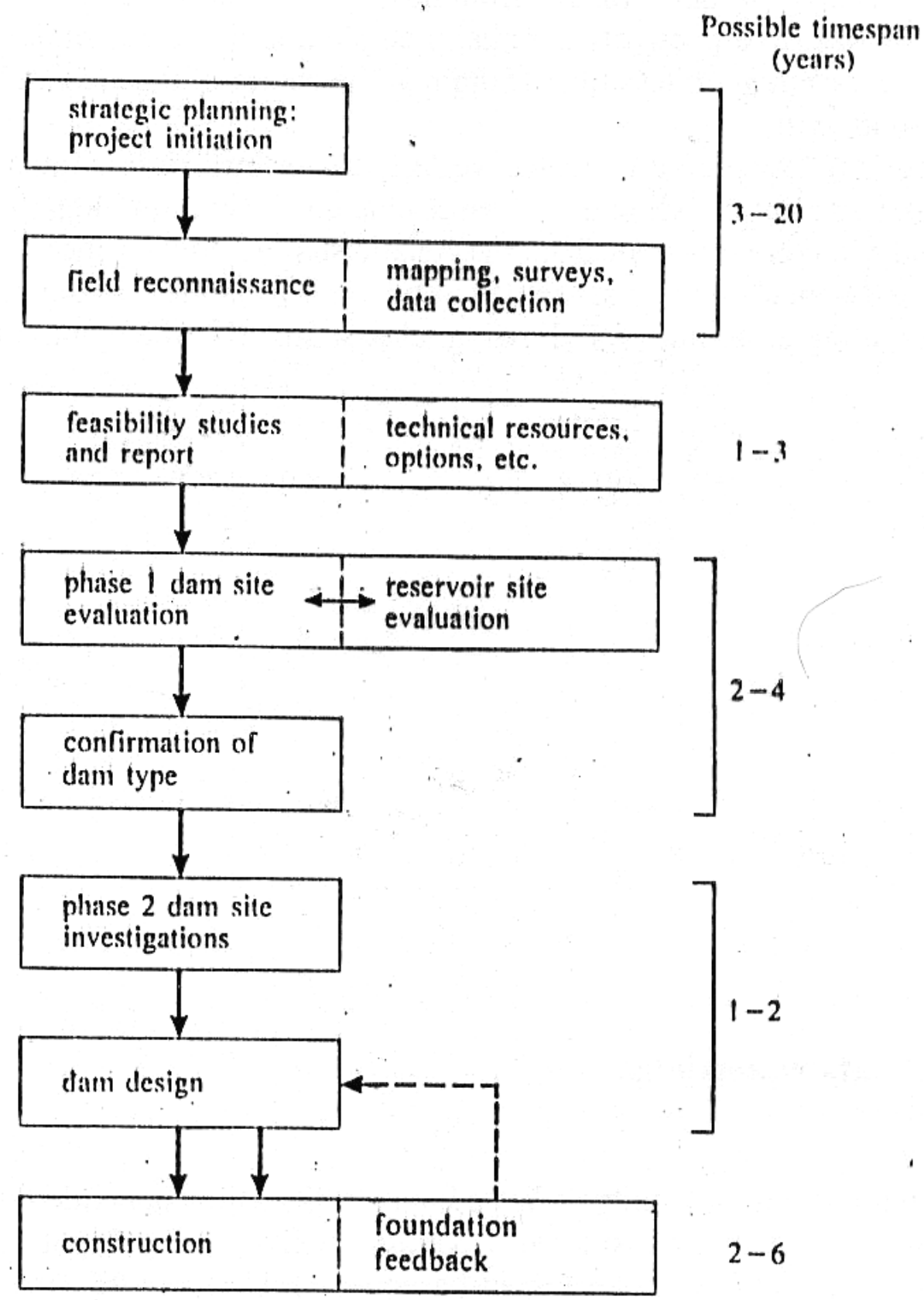

Fig 4. Stages in dam site appraisal and project development.

The mechanism of this method starts with the understanding of the concept and turn of the following parameters including requirements, satellite images, topographic maps, geological maps, soil maps, meteorological data, and field works. The requirements involve the various means which produce erosion sensitive sheet through 
studying drainage network characteristics, land cover properties, slopes, and soil and rock characteristics. Satellite images delineate the study area, land cover, and drainage network. Topographic maps show the details of drainage network. Geological maps dictate the rock characteristics at the site and its surround areas especially the rock resistance against erosion, sedimentation, and multiple loads .Soil maps show the relation between drainage, land cover, and erosion sensitive. Effect of meteorological parameters towards site selection including solar radiation, temperature, humidity, pressure, wind, evaporation, and precipitation. Field works are necessary for check up, modification, and addition new data for the required factors.

\section{ANALYSIS}

By applying the procedures of elimination method at Wala basin ,then insert that data into geographic information system (Arc info ,Arc view), a number of options will be obtained related to the sensitive erosion sheet of Wala dam site ; very high, high ,low , and very low erosion sensitive sheet .

As shown in Fig5, the satellite image covers the entire study area and its different features such as arid, green, hills, plains, wadies, and streams zones.

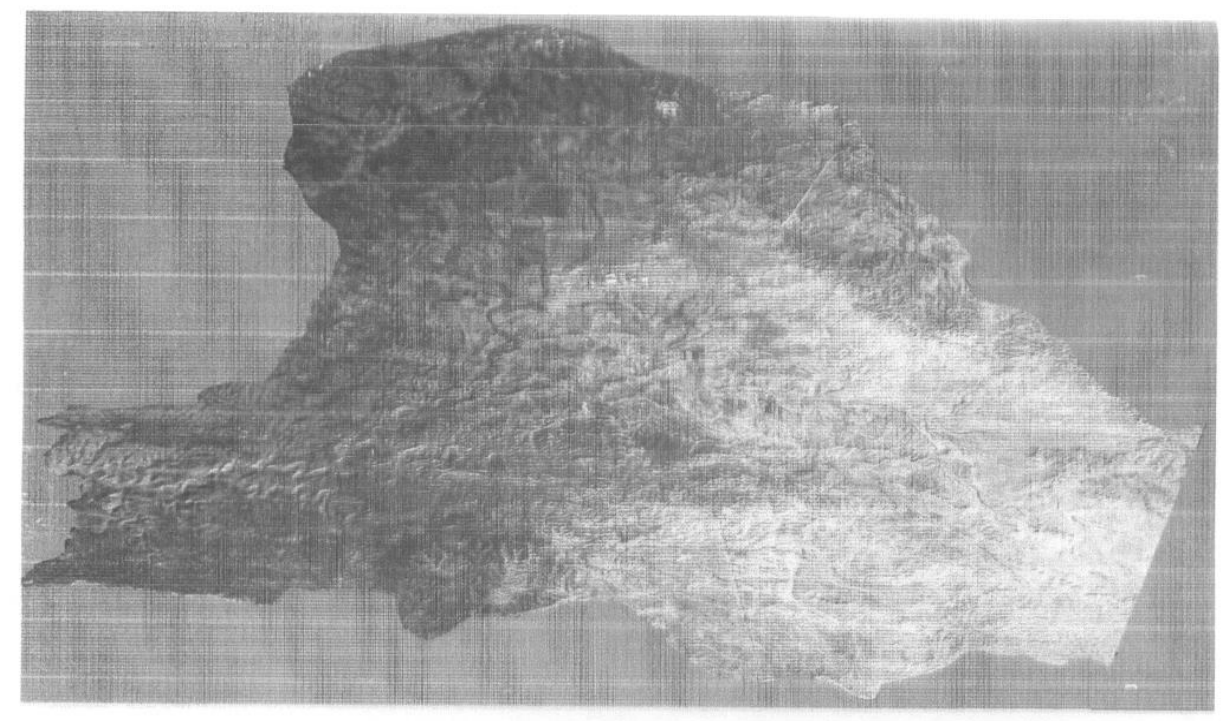

Fig 5. Image of study area.

Two sheets at least should be obtained from satellite image; land use and plant cover.Fig6 represents the map of land use which affect erosion by this or that according to the variation of coefficient factor for each type of features. 


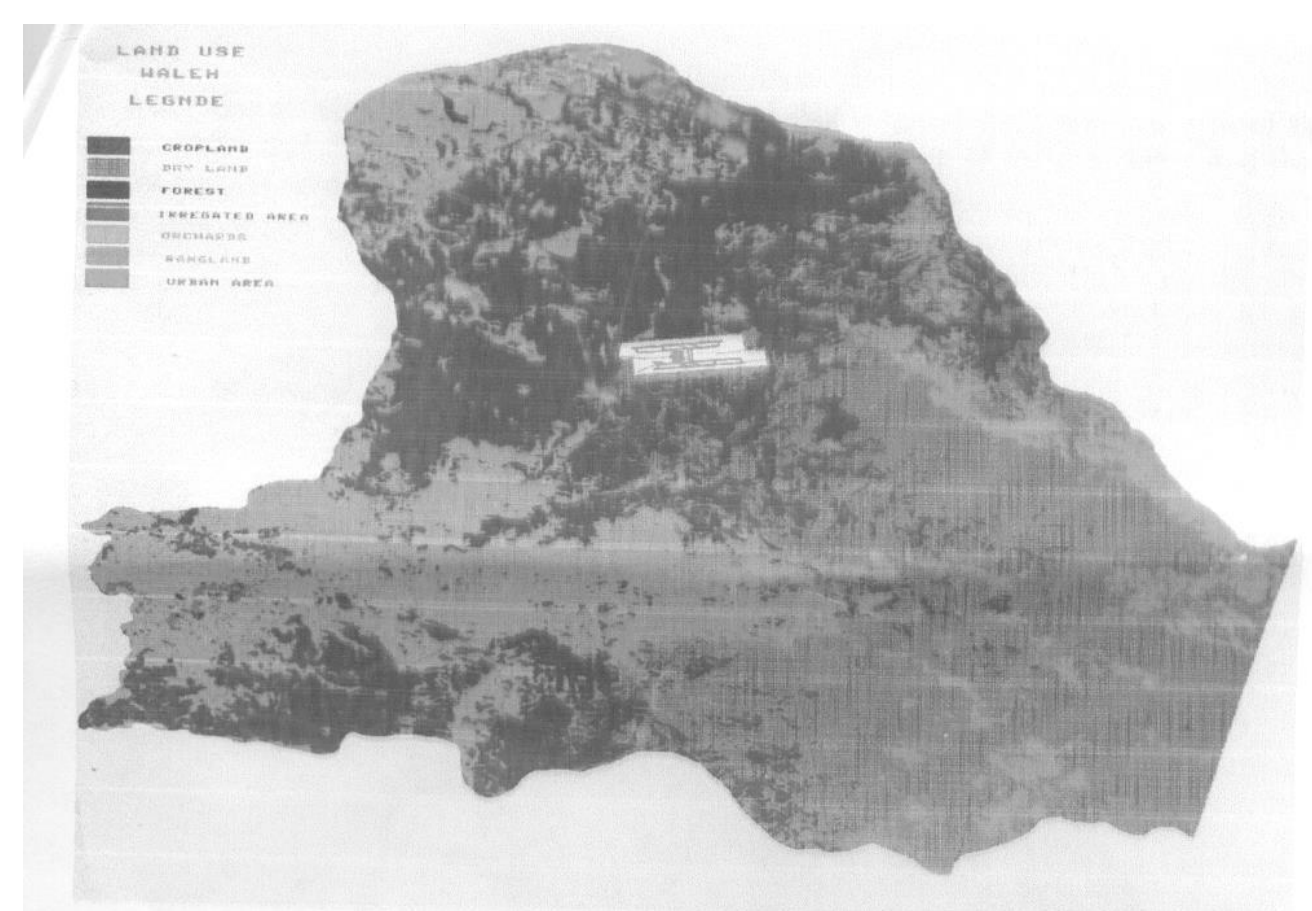

Fig 6. Land use of study area.

Figure 7 indicates the ratios of different types of plants among the whole area and what its effect towards soil erosion.

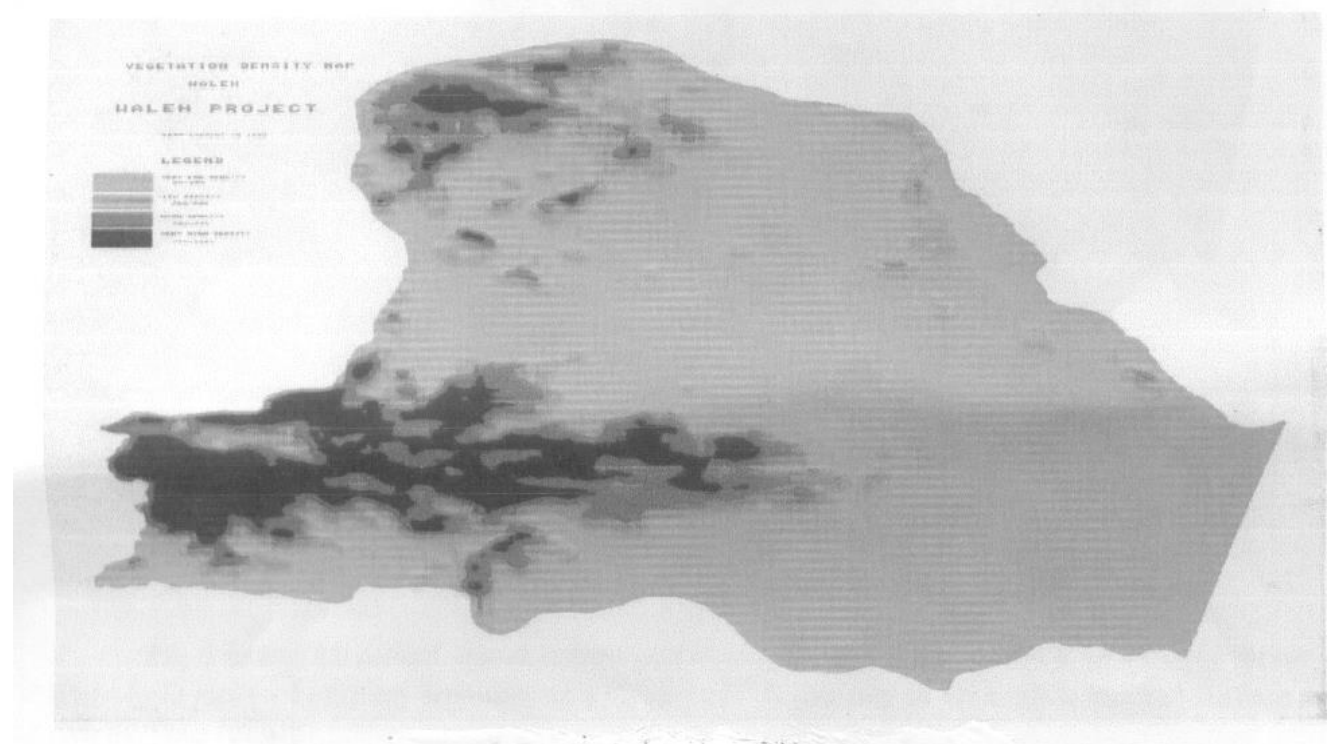

Fig 7. Vegetation density map of study area. 
Also, two sheets can be produced from topographic maps of the catchment area of the basin; slopes and drainage net work. Fig8 shows the percentage of various slopes and their effects towards runoff basically and erosion later on.

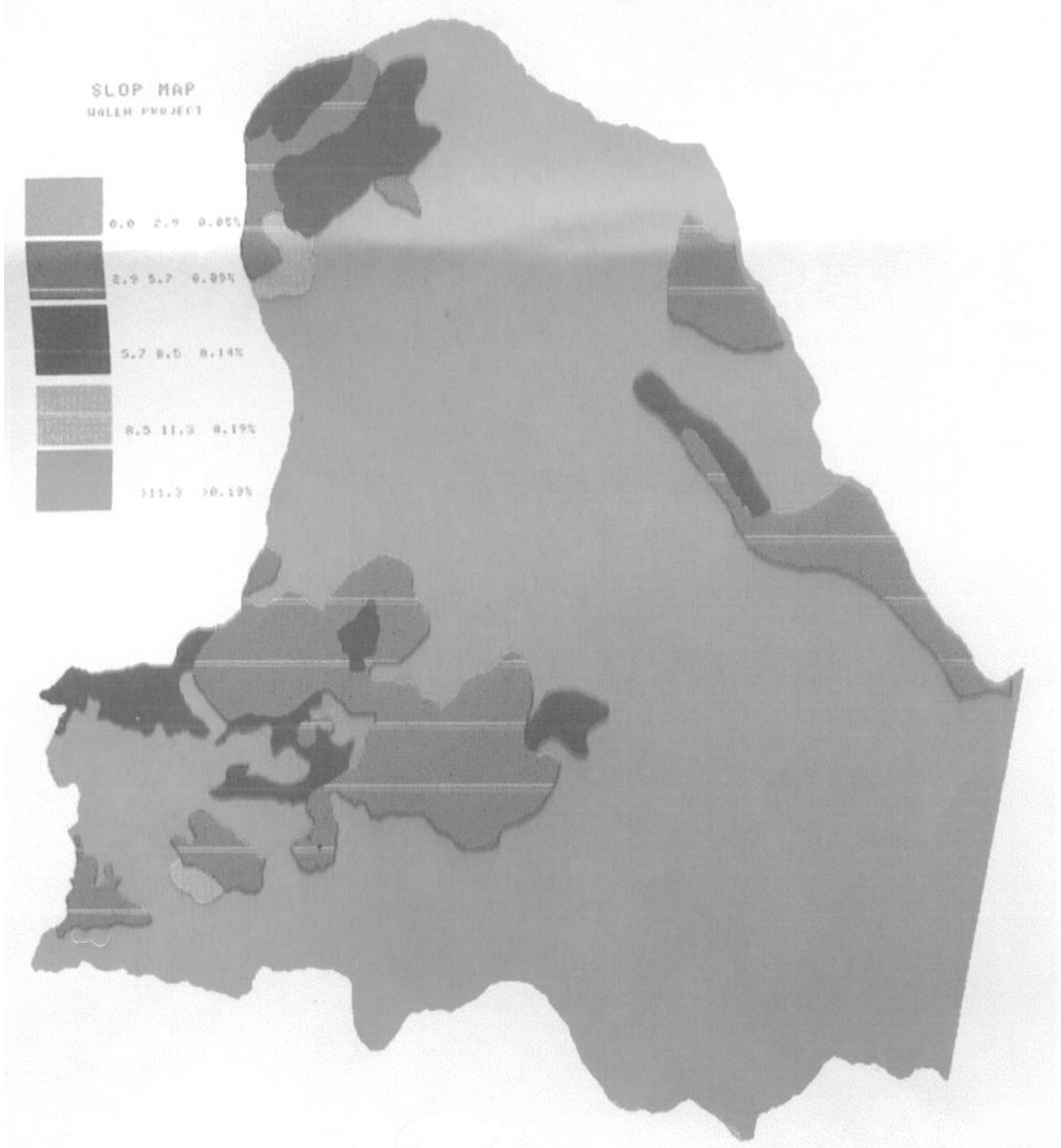

Fig 8. Slope map of study area.

Figure 9 to Fig 11 dictate the development of surface drainage network as a major factor of the whole story of erosion sensitive of soil through its journey or resistance against surface and sub-surface runoff. 


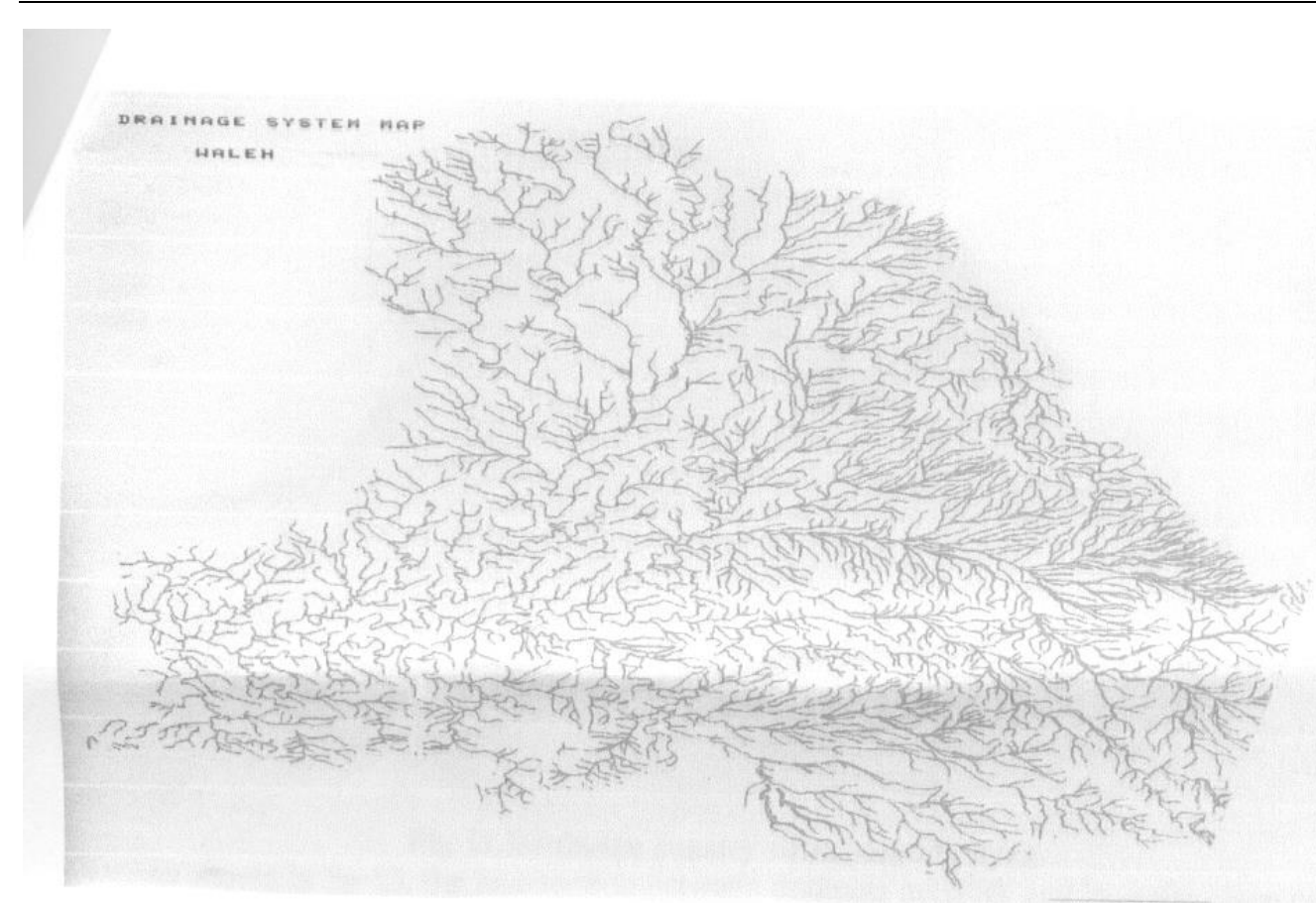

Fig 9. Drainage map of study area

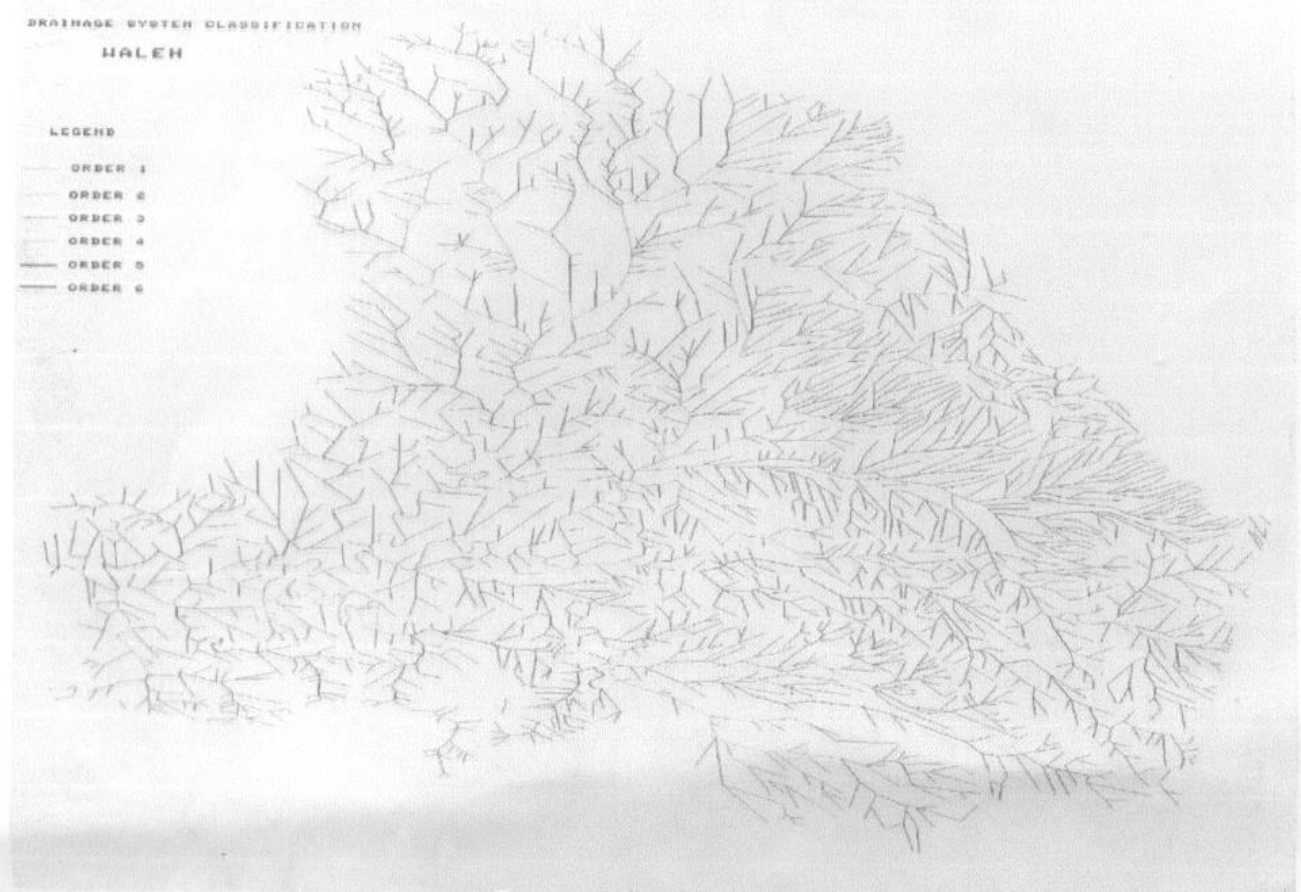

Fig 10. Drainage classification of study area. 


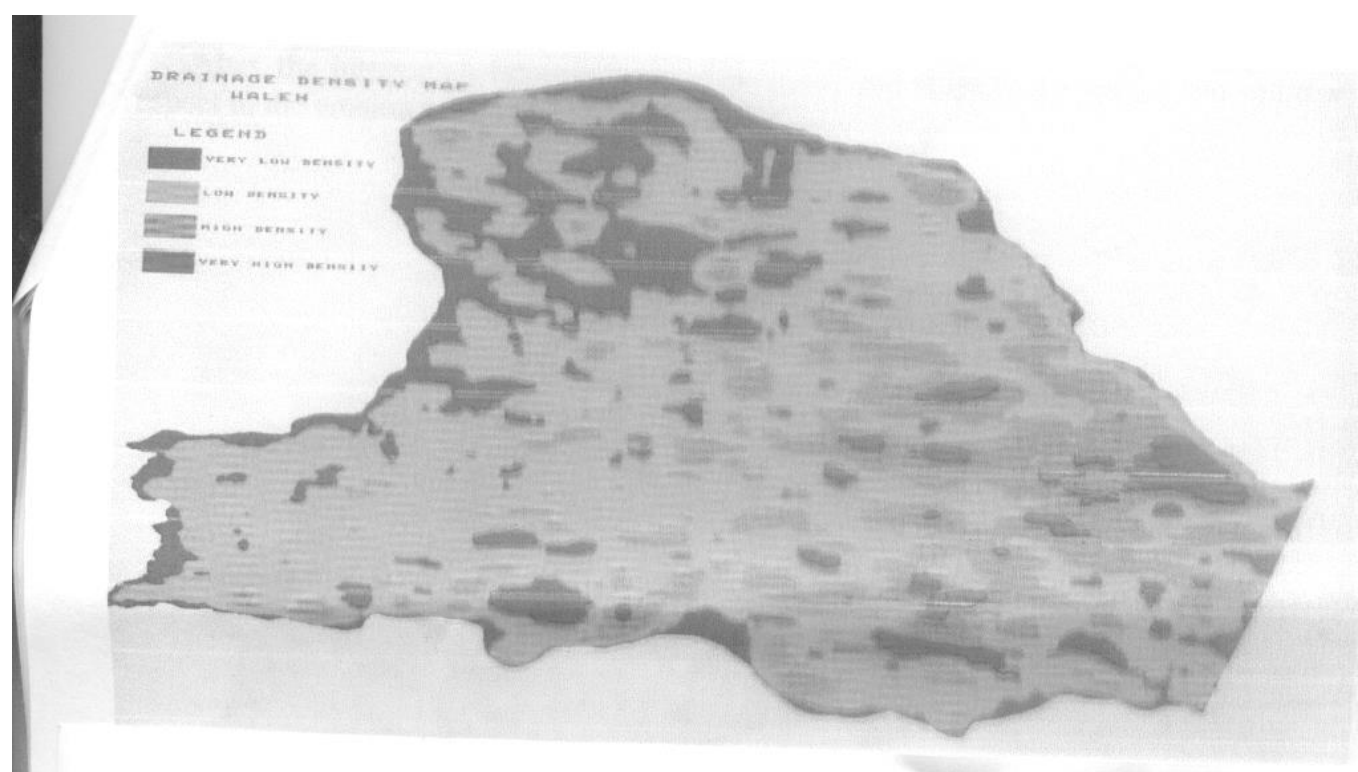

Fig 11. Drainage density ratio of study area.

As shown in fig 12, the intersection between drainage network and land use maps created a new sheet called integration of drainage density and materials (rocks and soil). Giving drainage (D1, D2), materials (M1, M2) four options can be shown according to the intersection of these parameters. Where $\mathrm{D}=$ drainage, $\mathrm{M}=$ material, $1=$ low, 2 = high.

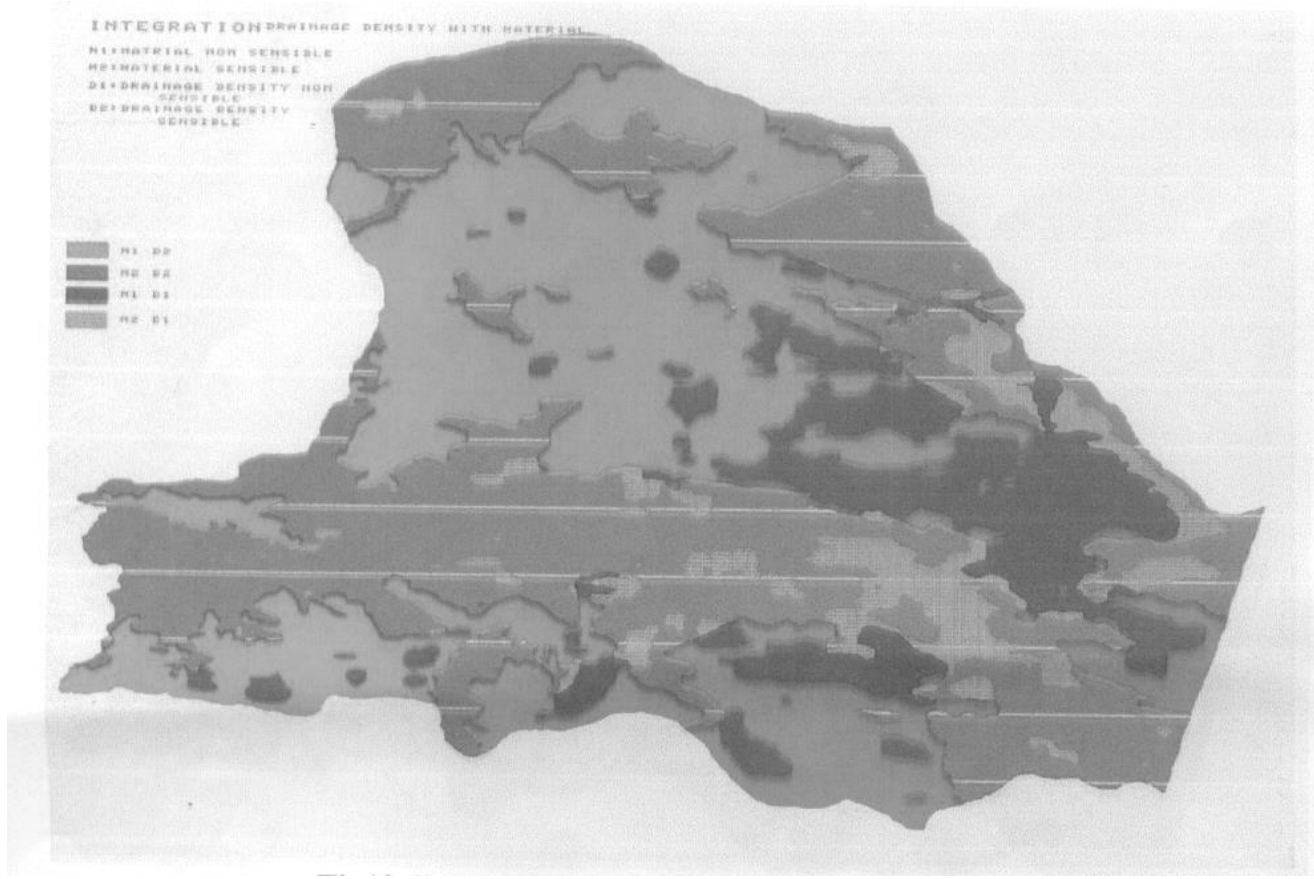

Fig12. Integration density of drainage and material. 
Also, the integration between vegetation covers and slope maps led to four options with respect to the erosion sensitive as shown in Fig 13.

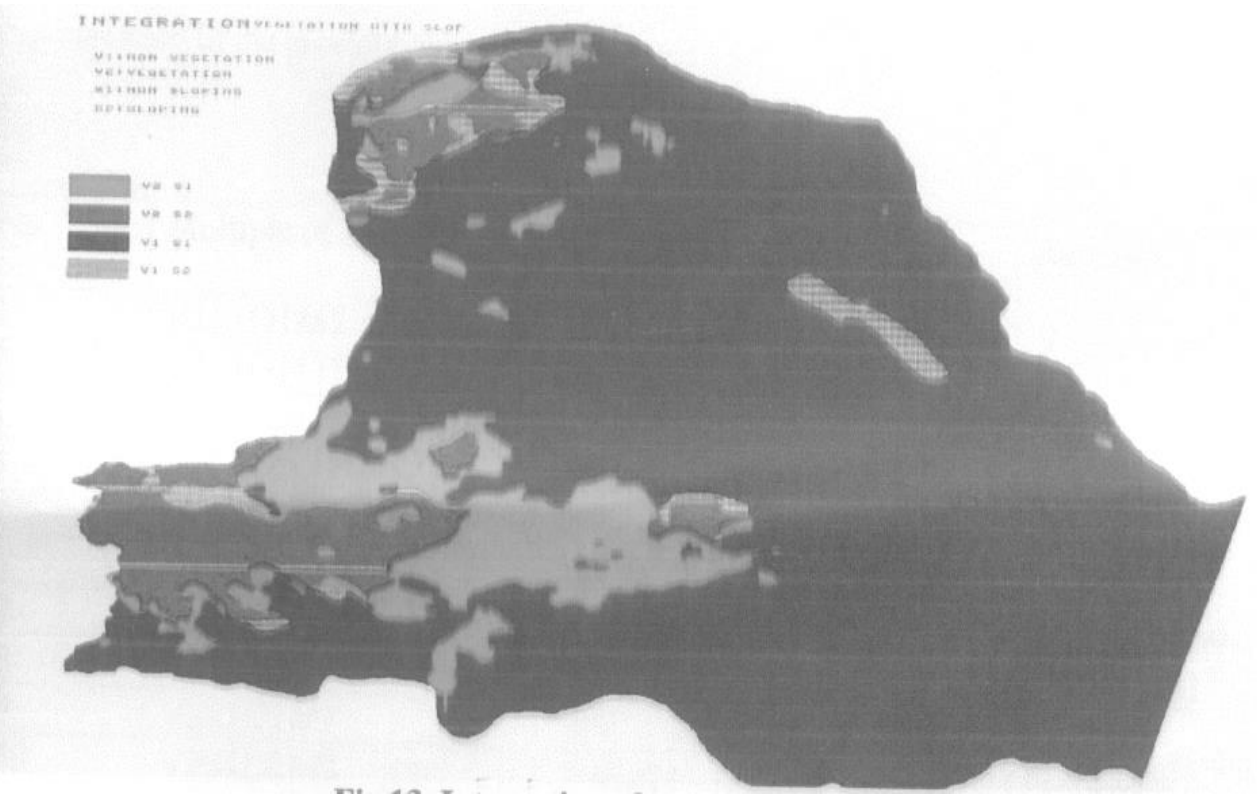

Fig 13. Integration of vegetation and slope.

The multiple of the previous options of integration sheets appeared in Fig 14 with 16 choices related to the soil erosion sensitive.

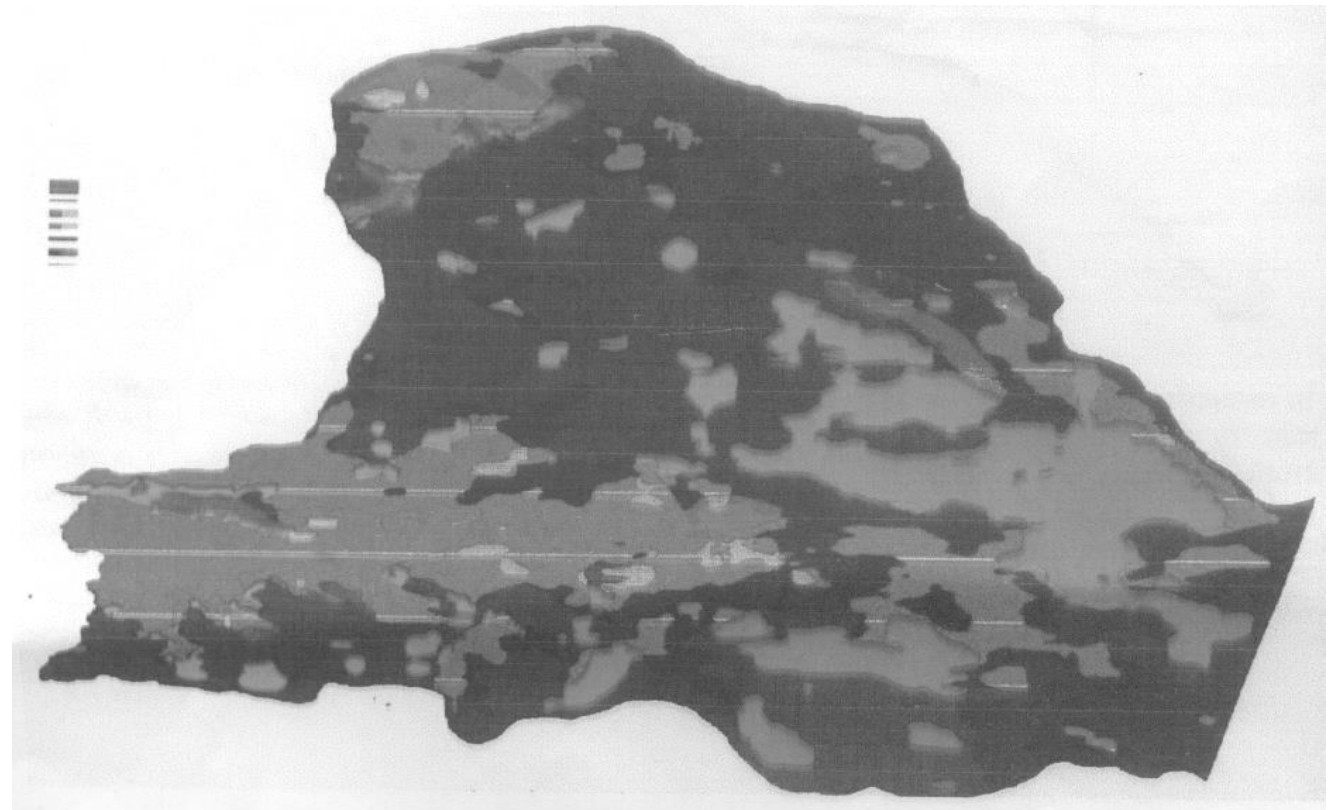

Fig 14 . Multiple of different parameters and integration sheets. 
The summary of the previous choices shown in table two.

\begin{tabular}{|c|c|c|c|}
\hline No & Multiple of options & High rank notation & Remarks \\
\hline 1 & V1S1D1M2 & M & \multirow{16}{*}{$\begin{array}{l}\mathrm{V}=\text { Vegetation } \\
\mathrm{S}=\text { Slope } \\
\mathrm{D}=\text { Drainage } \\
\begin{array}{l}\mathrm{M}=\text { Material } \\
\text { (rock, soil) }\end{array}\end{array}$} \\
\hline 2 & V1S1D1M1 & $\mathrm{N}$ & \\
\hline 3 & V1S1D2M2 & MD & \\
\hline 4 & V1S1D2M1 & $\mathrm{D}$ & \\
\hline 5 & V1S2D1M2 & SM & \\
\hline 6 & V1S2D2M2 & SDM & \\
\hline 7 & V1S2D2M1 & SD & \\
\hline 8 & V2S1D1M2 & VM & \\
\hline 9 & V2S1D1M1 & V & \\
\hline 10 & V2S1D2M2 & VMD & \\
\hline 11 & V2S2D1M1 & VS & \\
\hline 12 & V2S1D2M1 & VD & \\
\hline 13 & V2S2D1M2 & VSM & \\
\hline 14 & V2S2D2M1 & VSD & \\
\hline 15 & V2S2D2M2 & VSMD & \\
\hline 16 & V2S2D2M1 & VSD & \\
\hline
\end{tabular}

Table 1. Multiple of various parameters.

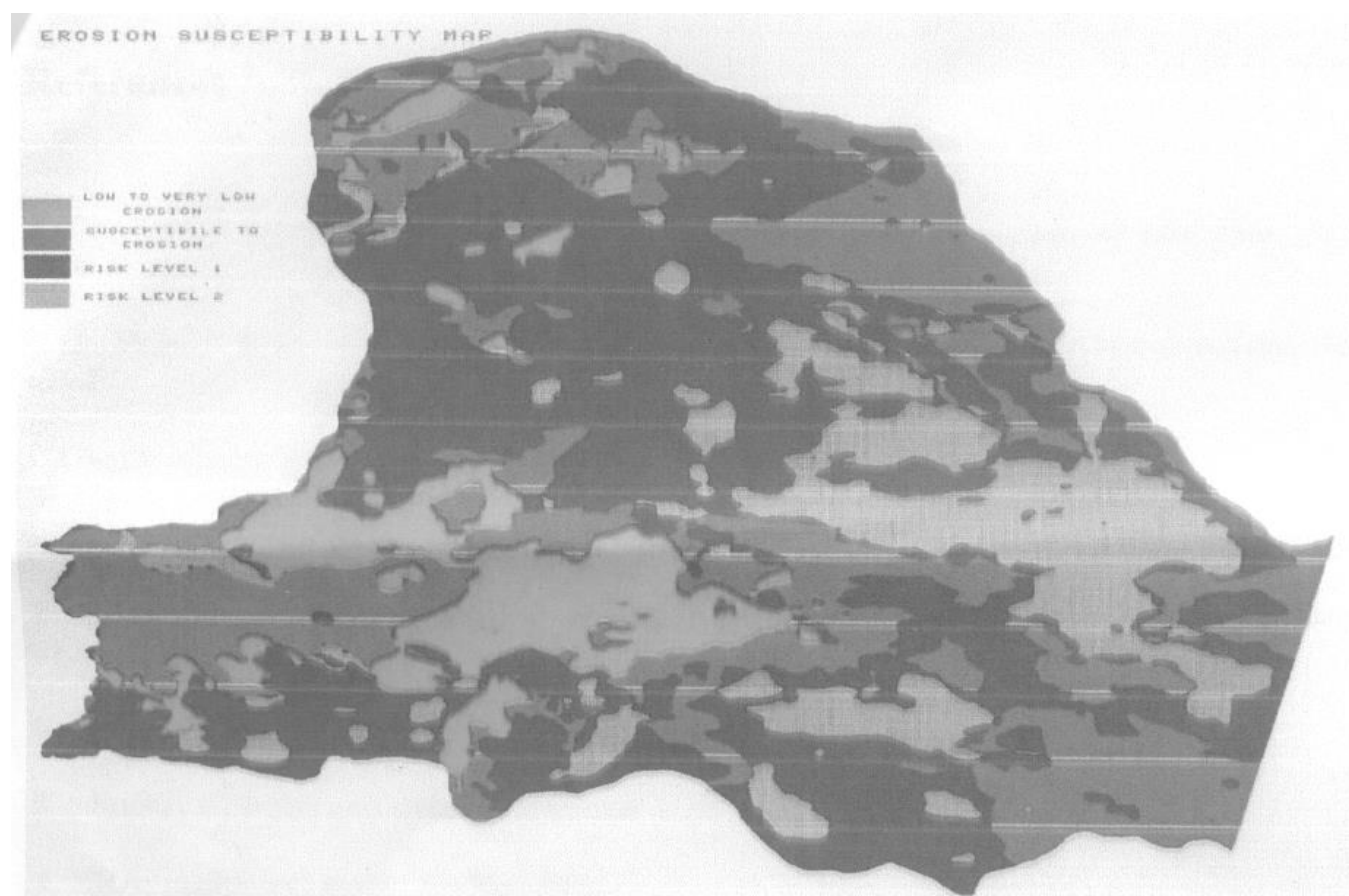

Fig 15. Erosion sensitive map.

Out of the sixteen options only four options were selected to represent the situation of dam site from point view of soil erosion sensitive. Fig 15 dictated that the best site of dam that position which has low sensitive of soil erosion. Besides that, there 
are number of factors also should be available at high standard. Well topography is necessary at dam shoulders and reservoir. Good characteristics of geological formations and soils are necessary for dam stabiliy. More amounts of runoff are required for full reservoir capacity.

\section{CONCLUSIONS AND RECOMMENDATIONS}

Jordan as example of arid region needs a lot of studies in order to store much surface and ground water during winter season in different means.

Dams still the major unique structures used for collecting surface water in order to minimize the gap between water supply and demand.

Site selection is the most important factor of dam establishment due to its effect towards hydrology, topography, and geology and dam safety.

Rs and GIS are proper tools of collecting and analysis data in proper way due to its use of sophisticated and high technology equipments and software.

Elimination method was the selective model and procedure of collecting, analysis, and output data from available resources in this paper because of its wide parameters and application simplification.

Finally, this case study and its tools and methodology were accepted by planners, and decisions makers to be applied it for other dam's site selection in the country.

\section{REFERENCES}

1. Dr. Abed "Jordan geology, Environment, and water", Association of Jordanian geologist, 2000.

2. Dr. Bohiri "Jordan Geography"Geographic Dept, Jordan University, Husini mosque library, 1991.

3. Ghalib Khalil "Geology of Madaba district", geological section, NRA, 1995.

4. Geographic information system “Arc info, Arc view”, ESRI, 2004.

5. Jackson T .J "Remote sensing of soil moisture: implication for ground water recharge, hydrogeogy Journal, 2002.

6. Ministry of agriculture "National Soil Map" Jordan, 1998.

7. Ministry of water and irrigation, annual publishing report, Jordan, 2004.

8. NRA, geological maps, Jordan, 2002.

9. Rami khouri “Jordan Valley", London, New York, 1981.

10. RJGC" Topographic maps and Geological maps of Jordan, 2002. Amman - Jordan. 


\section{العوامل الرئيسية المؤئرة في اختيار موقع سد الدالة}

يعتبر الماء مادة هامة للجنس البشري والمخلوقات الأخرى على سطح الأرض من أجل نموهم, وبقائهر

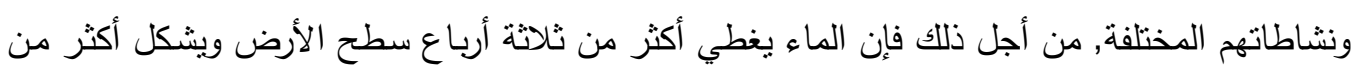

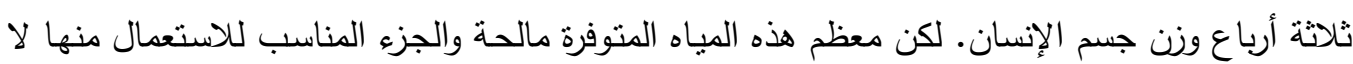

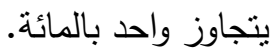

تقسم الكرة الأرضية حسب الهاطل المطري وبقية عوامل الأرصاد الجوية إلى مناطق رطبة بهاطل مطري

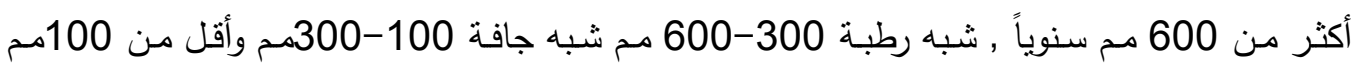
ل اللمناطق الجافة.

يقع الأردن في منطقة شبه جافـة, حيث يواجهه نقصـا بالهاطل المطري يومـا بعد يوم وتقل المصـادر

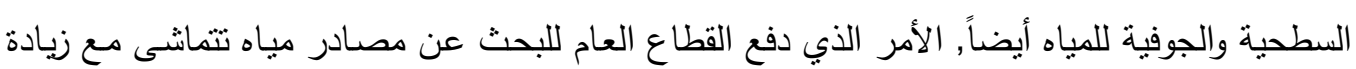
السكان وطلباتهم المتتامية. تعتبر السدود إحدى المنشآت المفضلة لحجز المياه السطحية وكل المياه الجوفية, لكنها تحتاج إلى المزيد نت الدراسة واستخدام أحدث الوسائل من المعدات والتكنولوجيا لتحقيق الأهداف المرجوة منها. يعتبر سد الوالة نقطة جذابة لدراسة الغوامل المؤثرة باختيار موقعة باستخدام التقنيات الحديثة من أجل التل إبراز دور المعلومات الضرورية, وتحليلها ومخرجاتها. 